Wojciech Bednarek

Uniwersytet Wrocławski

DOI: 10.19195/2450-274X.2.4

\title{
Unijna polityka migracyjna wobec obywateli państw Europy Wschodniej - w stronę liberalizacji czy ograniczania swobody przypływu osób?
}

Abstrakt: Celem tego artykułu jest przegląd unijnej polityki w zakresie wspierania i promocji mobilności społeczeństw państw z obszaru Partnerstwa Wschodniego. Omówione zostają następujące instrumenty: liberalizacja wizowa, rozwijanie mobilności społecznej w rejonach przygranicznych, promocja europejskiego rynku pracy i edukacji. Przyciąganie wartościowego kapitału ludzkiego jest jednym z priorytetowych działań Unii Europejskiej na rzecz wspierania rozwoju gospodarczego i społecznego państw członkowskich. Jednocześnie rozwijanie przepływów ludzkich pomiędzy Unią a jej wschodnim sąsiedztwem uznawane jest za skuteczny element odziaływania na przemiany społeczno-polityczne w krajach byłego ZSRR i upowszechnianie na tym obszarze wartości europejskich. Wzrost napływu cudzoziemców z obszaru Europy Wschodniej ma istotne znaczenie dla bilansu migracyjnego Polski, która w ostatnim czasie staje się coraz popularniejszym celem migracji cyrkulacyjnych i osiedleńczych.

Słowa kluczowe: Europa Wschodnia, granice zewnętrzne, liberalizacja, migracje, mobilność, Partnerstwo Wschodnie, polityka migracyjna, Polska, Unia Europejska, wizy

The EU migration policy toward the citizens of countries of Eastern Europe liberalization or constraint of flow of citizens?

Abstract: This article gives a brief review of the EU's migration policy towards the Eastern Partnership. It seems that, due to the demographic changes, the acquisition of valuable human capital from this area will be crucial for maintaining economic and social development of EU's Member States in near future. At the same time supporting human flows between the EU and its Eastern Neighbourhood is considered as an effective instrument of promoting European values in 
post-Soviet region. The support for social mobility between the EU and Eastern Europe has particular importance for Poland which migration profile has changed significantly in recent years. Nowadays Poland is becoming a popular destination of circular and settlement migrations from that region.

Keywords: Eastern Europe, the European Union, external borders, inflow, local border movement, migration, social mobility, VFA\&R agreements

Partnerstwo Wschodnie (PW) jest unijnym instrumentem polityki zagranicznej, którego celem jest wspieranie rozwoju politycznego oraz społeczno-gospodarczego państw partnerskich z obszaru Europy Wschodniej oraz zacieśnienie ich stosunków z Unią Europejską. Jednym z głównych obszarów współpracy jest rozwój kontaktów międzyludzkich, promocja mobilności i przepływów ludzkich do Unii Europejskiej. Działanie to wpisuje się w szerszy kontekst unijnej agendy "Globalnego Podejścia na Rzecz Migracji i Mobilności”, którego celem jest lepsza koordynacja działań Unii w obszarze migracji skierowanych do krajów trzecich. Wypracowanie wspólnej polityki wobec obywateli państw trzecich przekraczających granicę Unii z zamiarem pobytu, osiedlenia się lub podjęcia pracy na jej terytorium stanowi obecnie jedno z najważniejszych wyzwań dla UE, które w sposób zasadniczy będzie rzutować na dalszy rozwój europejskiego projektu integracyjnego. Analiza dokumentów strategicznych i programowych wskazuje, iż dwa główne obszary zainteresowania Unii w kwestii lepszego regulowania przepływów migracyjnych na szczeblu wspólnotowym to: zagwarantowanie wysokiego poziomu bezpieczeństwa wewnętrznego państw członkowskich oraz lepsze zarządzanie migracją ekonomiczną w celu stymulowania wzrostu gospodarczego Unii i państw wysyłających. Poza tym w swoich dokumentach Unia kładzie silny nacisk na to, by realizowane polityki w kwestii migracji i azylu były zgodne $z$ uniwersalnymi wartościami, jakie leżą u podstaw integracji europejskiej oraz powziętymi przez nią zobowiązaniami międzynarodowymi. W osiąganiu celów strategii polityki migracyjnej w jej zewnętrznym wymiarze Unia Europejska posługuje się szerokim wachlarzem narzędzi, do których zaliczają się: prawodawstwo (w postaci zawieranych umów międzynarodowych), instrumenty polityczne (np. pogłębione dialogi polityczne), a także wsparcie instytucjonalne, finansowe i pomoc techniczna udzielana państwom wysyłającym dla wzmocnienia ich zdolności do zarządzania przepływami migracyjnymi. Działania Unii realizowane są przy wsparciu wyspecjalizowanych biur i agencji (np. FRONTEX). Poza tym wiele europejskich programów w obszarze migracji wykonywanych jest przy zaangażowaniu organizacji międzynarodowych, organizacji pożytku publicznego, stowarzyszeń migrantów oraz środowisk eksperckich.

Niniejszy artykuł stanowi przegląd głównych narzędzi stosowanych przez Unię Europejską wobec jej wschodnich sąsiadów objętych programem „Partnerstwa Wschodniego" w obszarze promocji migracji i mobilności. Kwestia ta należy do jednego z najbardziej eksponowanych problemów w ocenie skuteczności PW i ma szczególnie ważny wymiar społeczny. Skuteczność Unii i poszczególnych 
państw członkowskich w tym zakresie niwelować będzie ryzyko powstawania „rowu tektonicznego" na jej wschodnich rubieżach, który będzie dzielił Europę oraz powstrzymywał oddziaływanie unijnych norm i wartości na całym kontynencie.

\section{Liberalizacja reżimu wizowego}

Najważniejszym udogodnieniem, jakie jest oferowane krajom objętym inicjatywą Partnerstwa Wschodniego na ich drodze do zbliżenia $z$ UE, jest liberalizacja reżimu wizowego wraz z perspektywą całkowitego zniesienia obowiązku posiadania wiz. Polityka wizowa Unii wobec obywateli państw Europy Wschodniej, której warunkom musiały podporządkować się również kraje przystępujące do wspólnoty w 2004 r., powoduje liczne ograniczenia w rozwoju współpracy, zarówno w politycznym, jak i społeczno-gospodarczym wymiarze. Utrudnienia są odczuwalne zwłaszcza przez nowych członków Unii, posiadających zewnętrzną granicę Schengen, którzy przed akcesją odnosili liczne korzyści z rozwoju transgranicznych kontaktów, mają silne związki kulturowo-historyczne z tym regionem, a obecnie wykazują także zainteresowanie zwiększeniem napływu migrantów. Również w wymiarze ogólnoeuropejskim polityka wizowa stanowi szczególnie wrażliwy element polityki sąsiedztwa — choć formalnie prowadzona wobec państw, w praktyce restrykcje dotyczą bezpośrednio obywateli ${ }^{1}$.

Stosowany przez Unię Europejską wobec wybranych państw trzecich proces liberalizacji wizowej składa się z dwóch etapów. Pierwszy z nich obejmuje zawarcie dwustronnych umów o ułatwieniach wizowych i readmisji. Umowy o ułatwieniach wizowych zwierają preferencje dla określonych grup podróżnych wnioskujących o wizy. Ułatwiania dotyczą zazwyczaj określonych grup zawodowych (np. kierowców, dziennikarzy, naukowców), kategorii wiekowych (np. emerytów, studentów, uczniów) lub deklarowanego celu wyjazdu (np. wyjazdu w celach kulturalnych, leczniczych, naukowych). Preferencje obejmują obniżenie lub zniesienie opłaty za rozpatrzenie wniosku wizowego, uproszczenie procedury składania wniosków wizowych, wydawanie wiz wielokrotnych z długim terminem ważności. Celem ułatwień wizowych jest wspieranie bezpośrednich kontaktów międzyludzkich oraz sprzyjanie rozwojowi związków gospodarczych, humanitarnych, kulturalnych, naukowych i innych ${ }^{2}$. Warunkiem zawarcia porozumienia o ułatwieniach wizowych jest zgoda państwa na związanie się umową o readmisji. Umowy te stanowią jedno z narzędzi, jakim posługuje się Unia, by przeciwdziałać nielegalnej migracji. Umowy o readmisji sankcjonują procedury odesłania do

${ }^{1}$ M. Zdanowicz, A. Doliwa-Klepacka, Możliwość liberalizacji reżimu wizowego $w$ ramach wspótpracy państw w Partnerstwie Wschodnim, [w:] Partnerstwo Wschodnie. Wymiary realnej integracji, red. M. Zdanowicz, T. Dubowski, A. Piekutowska, Warszawa 2010, s. 151.

${ }^{2}$ Ibidem, s. 152. 
państwa pochodzenia cudzoziemca, który nie posiada wymaganych dokumentów potwierdzających jego pobyt.

$\mathrm{W}$ ramach drugiego etapu - tzw. dialogu wizowego - Komisja Europejska przedstawia krajom partnerskim plan działania w zakresie liberalizacji wizowej (VLAP), który obejmuje cztery bloki zagadnień: 1. bezpieczeństwo dokumentów, 2. zintegrowane zarządzanie granicami i migracjami oraz polityka azylowa, 3. bezpieczeństwo wewnętrzne, $w$ tym walka $\mathrm{z}$ korupcją, 4. ochrona mniejszości i prawa antydyskryminacyjne. $\mathrm{W}$ ramach każdego $\mathrm{z}$ bloków państwa objęte tą procedurą zobowiązują są do wprowadzenia odpowiednich rozwiązań prawnych i organizacyjnych, które zbliżą ich prawodawstwo z zasadami i normami funkcjonującymi w UE. Komisja monitoruje postępy państw we wdrażaniu zobowiązań wynikających z przyjętego planu działań. Implementacja wszystkich postanowień może ostatecznie skutkować decyzją Komisji o zniesieniu wiz, na którą jednak potrzebna jest zgoda Parlamentu Europejskiego i Rady UE.

Liberalizacją wizową zainteresowane są wszystkie kraje objęte programem Partnerstwa Wschodniego, choć prezentują różny stopień zaangażowania w proces wdrażania unijnych reform. Jedynym jak dotąd państwem PW, wobec którego wprowadzony został ruch bezwizowy, jest Mołdawia. Postanowienie o zniesieniu wiz dla obywateli Mołdawii posiadających paszporty biometryczne weszło w życie 28 kwietnia 2014 r. Pozostałe kraje, poza Białorusią, posiadają podpisane umowy o ułatwieniach wizowych. Najbliżej zniesienia wiz znajdują się Ukraina i Gruzja, wobec których wszczęto drugi etap liberalizacji wizowej. Plan działań wobec Gruzji został przedstawiony na początku 2013 r. Dialog wizowy pomiędzy Unią Europejską a Ukrainą rozpoczął się jeszcze w 2010 r., jednak opieszałość poprzednich władz we wprowadzaniu niezbędnych reform sprawiła, że dopiero w $2014 \mathrm{r}$. Ukraina podjęła realne kroki na rzecz jego realizacji. W czerwcu 2014 r. Rada UE postanowiła, że kraj ten wypełnił pierwszą, legislacyjną fazę VLAP i jest gotów do przeprowadzenia reform implementacyjnych, w ramach tzw. drugiej fazy ${ }^{3}$. Kwestia liberalizacji wizowej w ostatnim czasie nabrała szczególnego znaczenia w polityce zagranicznej Ukrainy. W powszechnym odbiorze społecznym ewentualną decyzję o zniesieniu obowiązku wizowego postrzega się nie tylko w wymiarze praktycznym, ale i symbolicznym - jako fakt uznania przez Unię proeuropejskich aspiracji Ukrainy, które tak silnie eksponowane były podczas rewolucji na Majdanie. Zarówno władze ukraińskie, jak i gruzińskie z rozczarowaniem odniosły się do deklaracji szczytu Partnerstwa Wschodniego w Rydze w maju 2015 r., ponieważ nie sprecyzowano w niej daty zniesienia wiz wobec tych krajów. Istotny postęp w tej sprawie zanotowano dopiero pod koniec roku - 18 grudnia Komisja Europejska wydała raport, w którym stwierdziła, że Gruzja i Ukraina wypełniły konieczne techniczne zobowiązania, przygotowujące je do zniesienia wiz.

${ }^{3}$ M. Jaroszewicz, Ukraina blizej ruchu bezwizowego z UE, „Analizy OSW”, http://www. osw.waw.pl/pl/publikacje/analizy/2015-11-18/ukraina-blizej-ruchu-bezwizowego-z-ue (dostęp: 19 grudnia 2015). 
Przywódcy państw i instytucji unijnych zapewniają o swoim poparciu dla zniesienia wiz wobec obywateli państw Europy Wschodniej, ale przypominają, że decyzja ta będzie uzależniona od wypełnienia przez partnerskie państwa wszystkich narzuconych wymagań. Wspólna polityka wizowa pozostaje ważnym elementem ochrony granic zewnętrznych UE, a w obliczu obecnego kryzysu migracyjnego kwestia ta nabrała szczególnego znaczenia. W społeczeństwach europejskich nieobce są także obawy, że zniesienie wiz dla państw Europy Wschodniej może spowodować napływ nielegalnych pracowników, co negatywnie wpłynie na kondycję europejskiej gospodarki. Z otwartością wobec migrantów z Europy Wschodniej mają również problem społeczeństwa nowych państw unijnych, których liderzy polityczni wykazują największe zaangażowanie w kwestii liberalizacji wizowej. Zdaniem Marty Jaroszewicz postawa ta wynika przede wszystkim z braku dotychczasowych doświadczeń imigracyjnych, homogeniczności społeczeństw, stosunkowo wysokiego poziomu ksenofobii: „Okazuje się zatem, że w wypadku liberalizacji wizowej i migracji z Europy Wschodniej do UE mamy do czynienia przede wszystkim ze zjawiskiem politycznym i społecznym, nie zaś ze znaczącym wyzwaniem demograficznym czy ekonomicznym"4.

\section{Mały ruch graniczny na zewnętrznych granicach Schengen}

Wprowadzenie wiz w ruchu osobowym ze wschodnimi sąsiadami spowodowało w nowych państwach członkowskich z obszaru Europy Środkowej zakłócenie porządku społeczno-gospodarczego, jaki w przeszłości przez wiele lat kształtował stosunki transgraniczne na ich wschodniej granicy. Rezultatem ograniczonego ruchu przez granicę były wymierne straty gospodarcze w rejonach utrzymujących się z handlu przygranicznego oraz zaburzenie więzi społecznych pomiędzy obywatelami sąsiadujących państw. W tej sytuacji niezwykle pożądanym rozwiązaniem było wdrożenie przepisów ustanawiających reżim małego ruchu granicznego (MRG) na zewnętrznych granicach Unii Europejskiej. MRG został ustanowiony na podstawie Rozporzadzenia Parlamentu Europejskiego i Rady na 1931/2006 z 20 grudnia 2006 r. Rozporządzenie nawiązuje do komunikatu Komisji $W$ kierunku zintegrowanego zarządzania granicami zewnętrznymi państw członkowskich Unii Europejskiej oraz Planu zarzadzania zewnętrznymi granicami państw członkowskich Unii Europejskiej zatwierdzonego przez Radę Europejską w Sewilli 21 i 22 czerwca 2002 r. Jak zaznaczono w preambule, podjęcie działań $\mathrm{w}$ celu ustanowienia specjalnej procedury wjazdu na terytorium strefy Schengen

${ }^{4}$ M. Jaroszewicz, Czego można oczekiwać po zniesieniu wiz dla obywateli Europy Wschodniej, „Biuletyn Migracyjny” 2014, nr 48, http://www.biuletynmigracyjny.uw.edu.pl/48-czerwiec-2014/ czego-mozna-oczekiwac-po-zniesieniu-wiz-dla-obywateli-europy-wschodniej (dostęp: 24 listopada 2015). 
dla mieszkańców strefy przygranicznej było podyktowane chęcią zagwarantowania, że granice państw członkowskich nie będą stanowiły barier dla handlu, wymiany społecznej i kulturalnej czy współpracy regionalnej.

Rozporządzenie definiuje mały ruch graniczny jako regularne przekraczanie zewnętrznej granicy lądowej przez osobę zamieszkującą strefę przygraniczną w celu pobytu w strefie przygranicznej ze względów społecznych, kulturalnych, uzasadnionych powodów ekonomicznych lub ze względów rodzinnych. Za strefę przygraniczną uważa się co do zasady pas o szerokości $30 \mathrm{~km}$. Jednostki administracyjne, których granice wykraczają poza obszar $30 \mathrm{~km}$, również uważa się za należące do strefy przygranicznej pod warunkiem, że nie sięgają dalej niż $50 \mathrm{~km}$ od granicy. Mieszkańcy strefy przygranicznej mogą przekraczać zewnętrzną granicę Schengen oraz poruszać się w strefie przygranicznej bez konieczności posiadania wizy. Prawo wjazdu oraz pobytu gwarantuje posiadanie specjalnego zezwolenia. W celu jego uzyskania mieszkańcy strefy przygranicznej muszą spełnić kilka wymogów określonych w przepisach wspólnotowych, w tym: udowodnić fakt stałego zamieszkania w strefie co najmniej od roku, posiadać ważny dokument podróży, nie figurować $w$ rejestrze systemu informacji Schengen ani w krajowych rejestrach uniemożliwiających wjazd na terytorium państwa członkowskiego.

Rozporządzenie ustanawiające przepisy, które dotyczą małego ruchu granicznego, stanowi istotne rozszerzenie dorobku prawnego Schengen. Jak zauważa Agnieszka Parol, przekraczanie granicy w ramach małego ruchu granicznego oznacza odstępstwo od ogólnych zasad określonych w Kodeksie Wizowym Schengen ${ }^{5}$. Zgodnie z obowiązującymi przepisami procedura wjazdu na terytorium Schengen jest wielostopniowa i powinna obejmować następujące etapy: weryfikacja spełnienia warunków umożliwiających wjazd, sprawdzenie dokumentów podróży pod kątem ich ewentualnego fałszerstwa, kontrola stempli wjazdu i wyjazdu, weryfikacja miejsca i celu planowanej podróży, potwierdzenie posiadania odpowiednich środków finansowych oraz sprawdzenie danych w bazie SIS II i bazach krajowych. Posiadacze zezwolenia MRG, oprócz tego, że są zwolnieni z obowiązku wizowego, nie muszą również okazywać dokumentów uzupełniających. Procedura ogranicza się jedynie do kontroli zezwolenia pod kątem możliwych fałszerstw oraz obowiązkowego sprawdzenia w rejestrze SIS II i bazach krajowych. Posiadacze zezwolenia MRG są również zwolnieni z wymogu uzyskania stempla w dokumencie podróży przy przekraczaniu granicy. Oprócz tego wspólnotowe przepisy o zasadach małego ruchu granicznego dają możliwość wdrażania przez zainteresowane państwa-strony dodatkowych ułatwień dla posiadaczy zezwoleń MRG. Przywileje te obejmują tworzenie specjalnych, dodatkowych przejść granicznych dostępnych tylko dla posiadaczy zezwolenia, wydzielanie na istniejących przejściach drogowych

${ }^{5}$ A. Parol, Konsekwencje członkostwa w Unii Europejskiej i strefie Schengen dla ruchu osobowego na wschodniej granicy Rzeczpospolitej Polskiej - analiza prawna, [w:] Wpływ acquis communautaire i acquis Scheng na prawo polskie - doświadczenia i perspektywy. Tom II: 15 lat acquis Schengen w prawie Unii Europejskiej, red. A. Kuś, A. Szachoń-Pszenny, Lublin 2014, s. 193. 
specjalnych pasów ruchu, udzielanie zgody na przekraczanie granicy w innych miejscach niż wydzielone przejścia graniczne.

Reżim małego ruchu granicznego na zewnętrznych granicach strefy Schengen zaczyna obowiązywać na podstawie umów dwustronnych zawieranych z zainteresowanymi państwami trzecimi. Umowy bilateralne doprecyzowują ogólne ustalenia zawarte w Rozporzadzeniu 1931/2006, w tym w szczególności wykaz jednostek administracyjnych wchodzących w skład strefy przygranicznej, minimalny okres zamieszkania w strefie konieczny dla skorzystania $\mathrm{z}$ zasad MRG, wykaz niezbędnych dokumentów, jakie należy okazać przy ubieganiu się o zezwolenie, procedurę wnioskowania, wysokość opłat oraz czas oczekiwania na wydanie dokumentu. Dotychczasowa praktyka wskazuje, że większość krajów członkowskich stosuje bardziej restrykcyjne rozwiązania niż minimalne wymogi określone we wspomnianym rozporządzeniu ${ }^{6}$.

MRG jest skutecznym narzędziem budowania relacji transgranicznych między Unią Europejską a jej wschodnim sąsiedztwem, o czym świadczy ilość zawartych umów bilateralnych. Największym beneficjentem wprowadzonego reżimu jest Ukraina, która ma obowiązujące umowy z Węgrami (od 14 grudnia 2007 r.), Słowacją (od 27 września 2008 r.), Polską (od 1 lipca 2009 r.) oraz z Rumunią (od 14 maja 2015 r.). Rumunia posiada również umowę o MRG z Mołdawią, która weszła w życie 26 lutego 2010 r. Państwa strefy Schengen - Polska, Łotwa oraz Norwegia - zawarły także umowy o małym ruchu granicznym z Rosją. W przypadku polsko-rosyjskiej umowy (weszła w życie 27 lipca 2012 r.) Komisja Europejska zgodziła się na zastosowanie rozwiązań szczególnych, wychodzących poza ramy prawne Rozporzadzenia 1931/2006 w zakresie dopuszczalnej wielkości strefy przygranicznej. Pozwoliło to na objęcie małym ruchem granicznym całego Obwodu Kaliningradzkiego i adekwatnego pod względem powierzchni obszaru leżącego na terytorium Polski (obejmującego gminy wchodzące w skład województw: pomorskiego i warmińsko-mazurskiego). Wprowadzeniem ułatwień w przekraczaniu granicy dla mieszkańców strefy przygranicznej nie jest jak do tej pory zainteresowana Białoruś. Mimo iż kraj ten ma wynegocjowane i podpisane umowy z Litwą oraz Polską, nie mogą one wejść w życie, gdyż Mińsk nie dopełnił procedur ratyfikacyjnych. Oficjalnym powodem strony białoruskiej jest niewystarczający stan infrastruktury granicznej, który nie pozwala na zwiększenie ruchu osobowego na istniejących przejściach. W rzeczywistości zwłoka Białorusi z wprowadzeniem umów z życie ma swoje podłoże polityczne i gospodarcze - niechęć reżimu wobec zbyt częstych podróży obywateli na Zachód i obawa przed nadmiernym odpływem waluty.

Doświadczenia Polski wskazują, że wdrożenie przepisów o małym ruchu granicznym bardzo korzystnie wpływa na ożywienie relacji gospodarczych i społecznych w regionach przygranicznych. Według danych Straży Granicznej już w pierw-

${ }^{6}$ M. Zdanowicz, A. Doliwa-Klepacka, op. cit., s. 159. 
szym roku obowiązywania umowy o MRG między Polską a Ukrainą odnotowano ponad dwukrotny wzrost liczby cudzoziemców, którzy po przekroczeniu granicy poruszali się w strefie przygranicznej. W pierwszym kwartale $2010 \mathrm{r}$. wydatki poniesione przez cudzoziemców na terytorium strefy przygranicznej były blisko $45 \%$ wyższe niż w analogicznym okresie przed wejściem w życie umowy. W II kwartale 2010 r. liczba osób przekraczających granicę w ramach małego ruchu granicznego wyniosła 811 tys., a kwota wydatków przez nich poniesionych osiągnęła poziom 184 mln zł, co stanowiło blisko 20\% wszystkich wydatków cudzoziemców przekraczających zewnętrzną granicę Unii Europejskiej na terytorium Polski ${ }^{7}$. Wprowadzenie ułatwień w przekraczaniu granicy na wjazd do Polski dla mieszkańców Obwodu Kaliningradzkiego nie tylko wpłynęło na wzrost obrotów handlowych w regionie, ale także miało korzystny wpływ na rozwój lokalnej turystyki ${ }^{8}$. Z cyrkulacyjnych migracji zarobkowych pomiędzy Europą Wschodnią a obszarem Unii Europejskiej wymierne korzyści czerpią również państwa wysyłające. Możliwość podjęcia pracy za granicą pozwala redukować nadwyżkę na rynku pracy, a dochody przesyłane przez migrantów są istotnym czynnikiem wspomagającym gospodarstwa domowe ${ }^{9}$.

Rozwiązania dotyczące zatrudniania cudzoziemców na terytorium UE podejmowane są zarówno na szczeblu wspólnotowym, jak i państwowym. Unijne prawodawstwo nadaje ogólne ramy procesowi pozyskiwania cudzoziemskiego kapitału ludzkiego, natomiast polityki migracyjne poszczególnych państw precyzują charakter, kierunki napływu oraz wielkość strumieni migracji pracowniczych ${ }^{10}$. Napływ pracowników z obszaru Partnerstwa Wschodniego na terytorium UE napotyka na przeszkody w postaci obowiązku wizowego, restrykcji pobytowych oraz ograniczeń w dostępie do miejscowych rynków pracy. Część państw unijnych, w tym Polska, podjęły jednak w ostatnim czasie aktywną politykę służącą promocji migracji pracowniczych z Europy Wschodniej. Ułatwiony dostęp wybranych grup cudzoziemców z obszaru Partnerstwa Wschodniego oraz Rosji do polskiego rynku pracy wprowadziło Rozporzadzenie Ministra Pracy i Polityki Społecznej $z$ dnia 20 lipca 2011 r. w sprawie przypadków, w których powierzenie wykonywania pracy cudzoziemcowi na terytorium Rzeczpospolitej Polskiej jest dopuszczalne bez konieczności uzyskania zezwolenia na pracę. Tzw. system oświadczeń ograniczający do minimum obowiązki formalne ze strony pracodawcy i ułatwiający cudzoziemcom uzyskanie wizy znajduje zastosowanie głównie przy poszukiwaniu pra-

${ }^{7}$ Ibidem, s. 162.

${ }^{8}$ K. Dudzińska, A.M. Dyner, Mały ruch graniczny między obwodem kaliningradzkim a Polska - wyzwania, szanse i zagrożenia, „PISM Policy Paper” 2013, nr 29.

${ }^{9}$ W dniu 4 lipca 2016 r. w związku z organizacją na terytorium Polski Szczytu NATO oraz Światowych Dni Młodzieży władze polskie zdecydowały o czasowym zawieszeniu obowiązywania umów o małym ruchu granicznym z Rosją oraz Ukrainą. Mały ruch graniczny z Ukrainą został wznowiony 3 sierpnia 2016 r., natomiast ograniczenia nie zostały zniesione w małym ruchu granicznym z Obwodem Kaliningradzkim. Władze polskie tłumaczą ten krok względami bezpieczeństwa państwa.

${ }_{10}$ Ibidem, s. 59. 
cowników do prac sezonowych i zajęć niewymagających wysokich kwalifikacji. Poza trybem uproszczonym cudzoziemcy mogą ubiegać się o legalne zatrudnienie w Polsce na podstawie zezwoleń na pracę wydanych przez wojewodę. Dane Ministerstwa Pracy i Polityki Społecznej wskazują na ogromną popularność uproszczonej formy zatrudniania cudzoziemców. W pierwszym półroczu 2015 r. zarejestrowano ponad 410 tys. oświadczeń, z czego znaczną większość (ponad 402 tys.) stanowiły oświadczenia wydane dla obywateli Ukrainy. Dla obywateli Mołdawii wydano ponad 3600 oświadczeń, Białorusi - ponad 2300, Rosji - 918, Gruzji - 829, a Armenii - 467. Promocji cyrkulacyjnej migracji zarobkowej na terytorium UE służą także bilateralne umowy o zatrudnianiu cudzoziemców w krajach członkowskich w systemie kwotowym, które określają maksymalne limity ilościowe imigrantów, jacy mogą ubiegać się o zatrudnienie oraz sektory, gdzie ich praca jest najbardziej pożądana. Wobec wschodnich sąsiadów UE porozumienia tego typu stosowane są w polityce migracyjnej Włoch, Francji czy Hiszpanii.

Dla rozwoju gospodarki europejskiej w perspektywie średnio- i długookresowej istotne znaczenie ma pozyskiwanie pracowników posiadających wysokie, często specjalistyczne kwalifikacje. Zwiększaniu siły przyciągania UE w pozyskiwaniu zagranicznego kapitału ludzkiego służy tzw. Dyrektywa Niebieskiej Karty (Dyrektywa 2009/50/WE w sprawie warunków wjazdu i pobytu obywateli państw trzecich $w$ celu podjęcia pracy $w$ zawodzie wymagajacym wysokich kwalifikacji). Również poszczególne państwa członkowskie na gruncie własnego prawodawstwa wprowadzają szereg rozwiązań skierowanych do pracowników wysoko wykwalifikowanych, takich jak obowiązująca w Niemczech, Czechach i Irlandii Zielona Karta, dająca określonym pracownikom prawo do pobytu długookresowego. Innym, stosowanym również w Polsce rozwiązaniem jest preferencyjne traktowanie cudzoziemców podejmujących studia w państwie przyjmującym, którzy po uzyskaniu dyplomu mogą ubiegać się o pracę na warunkach równych obywatelom tych państw. Przepisy te niewątpliwie sprzyjają napływowi cudzoziemskich studentów. Ze względu na bliskość geograficzną oraz bogatą ofertę stypendialną i naukową polskich uczelni, skierowaną do obywateli państw Europy Wschodniej, jednym z najpopularniejszych kierunków migracji edukacyjnych z obszaru PW jest Polska — w roku akademickim 2014/2015 na polskich uczelniach studiowało ponad 46 tys. obcokrajowców. Najliczniejszą grupę narodową stanowią Ukraińcy (ponad 23 tys.) oraz Białorusini ( 4,1 tys.).

\section{Wnioski}

Kwestie związane z promocją migracji i mobilności społeczeństw państw Europy Wschodniej do krajów Unii Europejskiej są stałym elementem aktywności dyplomatycznej Polski na forum UE. Zwiększanie bezpośrednich kontaktów międzyludzkich jest uważane przez polskie władze za jedną z najskuteczniejszych 
metod oddziaływania na prodemokratyczne przemiany na wschodzie Europy. $\mathrm{Z}$ tego powodu Polska konsekwentnie wspiera starania państw zaangażowanych w program Partnerstwa Wschodniego na rzecz liberalizacji i całkowitego zniesienia reżimu wizowego. Przy zainteresowaniu i wsparciu Polski wypracowywane są także inne instrumenty unijne, pozwalające na szerszy dostęp do unijnego rynku pracy czy edukacji.

Utrzymujący się na większości obszaru państw PW obowiązek wizowy przy wjeździe na terytorium UE stanowi najpoważniejszy czynnik ograniczający mobilność społeczną pomiędzy Unią a jej wschodnimi sąsiadami. Wymóg ten nie tylko utrudnia rozwój kontaktów społecznych, zmniejsza potencjał gospodarczy regionów przygranicznych, lecz także ogranicza zdolność konkurowania Unii w przyciąganiu wartościowego kapitału ludzkiego z obszaru Europy Wschodniej. Postępy na drodze liberalizacji wizowej względem państw Partnerstwa Wschodniego (lub ich brak) są jednym z najważniejszych kryteriów oceny skuteczności tego procesu integracyjnego. Opóźnienia we wdrażaniu planu liberalizacji wizowej w dużej mierze ponoszą same zainteresowane państwa, które pomimo składanych deklaracji politycznych nie zawsze wykazują wystarczającą determinację we wdrażaniu niezbędnych reform.

Za niewątpliwy i długo oczekiwany sukces należy uznać konkluzje raportu Komisji Europejskiej z dnia 18 grudnia 2015 r., który informuje o spełnieniu przez Ukrainę i Gruzję warunków do wprowadzenia ruchu bezwizowego z Unią Europejską. Decyzję tę musi zaaprobować jeszcze Parlament Europejski oraz Rada Unii Europejskiej. O ile na poziomie PE nie należy spodziewać się utrudnień, o tyle Rada, reprezentująca rządy państw unijnych, może dążyć do odsunięcia tej decyzji w czasie. Obserwowany obecnie kryzys migracyjny sprawia, że niektóre z państw, pod wpływem krajowej opinii publicznej, mogą usztywnić swoje stanowisko w zakresie liberalizacji przepływu przez zewnętrzne granice Unii. Nie można również wykluczyć, że część państw będzie uzależniać swoją zgodę na zniesienie wiz dla państw Europy Wschodniej od osiągnięcia ogólnoeuropejskiego konsensusu w sprawie kwot przyjmowanych emigrantów z Bliskiego Wschodu. Należy zatem zakładać, że ostateczna decyzja Unii o zniesieniu wiz wobec państw PW, które wypełniły założenia VLAP, będzie miała charakter stricte polityczny.

Mobilność na wschodnich granicach Unii Europejskiej wspomaga instytucja małego ruchu granicznego. Instrument ten dowiódł swej skuteczności w znaczący sposób, dynamizując przygraniczne kontakty gospodarcze i społeczne. Ułatwienia w przekraczaniu granicy pozytywnie wpływają na rozwój rejonów przygranicznych, który w dużym stopniu uzależniony jest od intensywności transgranicznej wymiany handlowej. Oprócz handlu instytucja MRG pobudza także rozwój turystyki i związanych z nią branż, m.in. gastronomii, usług czy hotelarstwa, przyczyniając się do zmniejszenia bezrobocia w regionach przygranicznych. Dla mieszkańców rejonów przygranicznych zainteresowanych głównie turystyką zakupową zezwolenie MRG stanowi korzystną alternatywę wobec wiz — koszt jego 
uzyskania jest niższy niż wizy jednolitej Schengen, a okres ważności wynosi co najmniej jeden rok. Obserwowany w konsulatach państw UE spadek w ilości wydawanych zezwoleń MRG pokazuje, że popyt na ten dokument został w dużym stopniu zaspokojony. Z przywileju tego nie mogą niestety korzystać obywatele Białorusi. Perspektywy uruchomienia tego mechanizmu na pograniczu polsko-białoruskim i białorusko-litewskim są jak na razie nikłe. $\mathrm{W}$ przeciwieństwie do większości państw Partnerstwa Wschodniego Białoruś nie traktuje kwestii mobilności swojego społeczeństwa priorytetowo, a utrzymywanie utrudnień przy wjeździe na terytorium UE jest pod wieloma względami korzystne dla panującego reżimu. Zainteresowane kraje nie powinny jednak zaprzestawać wywierania nacisku na władze w Mińsku w sprawie implementacji zawartych umów.

Oprócz rozwiązań prawno-instytucjonalnych istotnym czynnikiem wspierania przepływów ludzkich na terytorium UE jest rozwój infrastruktury granicznej. Rozbudowa istniejących przejść oraz tworzenie nowych przepraw wydaje się działaniem koniecznym w kontekście dalszego wspierania mobilności. Stały wzrost wydawanych wiz oraz znacząca liczba wydanych zezwoleń MRG powoduje, że znacząco wzrasta liczba osób odprawianych na granicach. Wielogodzinne kolejki są nie tylko uciążliwe, ale stanowią duże utrudnienie dla międzynarodowych przewozów pasażerskich i handlu pomiędzy UE a Europą Wschodnią. Należy również wziąć pod uwagę istotny czynnik zapewnienia bezpieczeństwa na zewnętrznych granicach UE i przeciwdziałania przemytowi. Alternatywą dla drogich i wymagających dużego wysiłku logistycznego przejść drogowych może być budowa mniejszych przepraw, przystosowanych wyłącznie do obsługi ruchu pieszego. To rozwiązanie może być szczególnie użyteczne przy obsłudze ruchu turystycznego i przygranicznego.

\section{Bibliografia}

Dudzińska K., Dyner A.M., Mały ruch graniczny między obwodem kaliningradzkim a Polska wyzwania, szanse i zagrożenia, „PISM Policy Paper” 2013, nr 29.

Jaroszewicz M., Czego można oczekiwać po zniesieniu wiz dla obywateli Europy Wschodniej, „Biuletyn Migracyjny" 2014 (czerwiec-lipiec), nr 48, s. 2, http://www.biuletynmigracyjny.uw.edu.pl/48-czerwiec-2014/czego-mozna-oczekiwac-po-zniesieniu-wiz-dla-obywateli-europy-wschodniej.

Jaroszewicz M., Ukraina bliżej ruchu bezwizowego z UE, „Analizy OSW”, 18.11.2015, http://www. osw.waw.pl/pl/publikacje/analizy/2015-11-18/ukraina-blizej-ruchu-bezwizowego-z-ue.

Lesińska M., Państwa Partnerstwa Wschodniego w polityce migracyjnej Polski i UE - dylematy i uwarunkowania, „Roczniki Nauk Społecznych” 2014, t. 6 (42), nr 3, s. 49-64.

Parol A., Konsekwencje członkostwa w Unii Europejskiej i strefie Schengen dla ruchu osobowego na wschodniej granicy Rzeczpospolitej Polskiej - analiza prawna, [w:] Wplyw acquis communautaire i acquis Scheng na prawo polskie - doświadczenia i perspektywy, tom II: 15 lat acquis Schengen w prawie Unii Europejskiej, red. A. Kuś, A. Szachoń-Pszenny, Lublin 2014.

Zdanowicz M., Doliwa-Klepacka A., Możliwość liberalizacji reżimu wizowego w ramach współpracy państw w Partnerstwie Wschodnim, [w:] Partnerstwo Wschodnie. Wymiary realnej integracji, red. M. Zdanowicz, T. Dubowski, A. Piekutowska, Warszawa 2010. 